RESEARCh PAPER

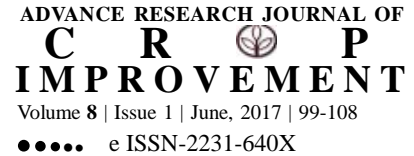

DOI :

10.15740/HAS/ARJCI/8.1/99-108

Visit us: www.researchjournal.co.in

\section{Effects of biofertilizers on plant growth and yield characters of Pisum sativum L.}

\author{
INSAF KHAN, DEVENDRA SINGH ${ }^{1}$ AND BHANWAR LAL JAT ${ }^{2}$
}

\section{Authors' Info \\ Associated Co-author : ${ }^{1}$ Department of Agriculture, Bhagwant University, AJMER, (RAJASTHAN) INDIA \\ ${ }^{2}$ Department of Agricultural Biotechnology Bhagwant University, AJMER (RAJASTHAN) INDIA}

Author for correspondence: INSAF KHAN

Department of Agriculture, Bhagwant University, AJMER, (RAJASTHAN) INDIA

Email: irfank428@gmail.com

\begin{abstract}
The present study was elucidated the effects of biofertilizers on plant growth and yield characters of Pisum sativum L. The research was conducted during Rabi 2016-2017 at the field experimentation centre of the Department of Agronomy, Bhagwant University Ajmer, during the year of 2016-2017. The data were recorded on 11 characters. Based on the mean performance the treatment- $8(100 \% \mathrm{RDF}+$ Rhizobium $30 \mathrm{~g} / \mathrm{kg})$ was found best treatment for plant growth and seed yield. This obtained high in plant height $(\mathrm{cm})$, number of primary branches per plant, number of leaves per plant, days to 50 per cent flowering, number of pods per plant, days to maturity, pod length $(\mathrm{cm})$, number of seed per pod, seed index, seed yield per plant, nodules per plant. Interaction effect of biofertilizers was significant for all characters. Thus, it indicates that the process of biofertilizers may be better option for seed growers to achieve seed yield and yield components in pea.
\end{abstract}

KEY WORDS : Azotobactor, Rhizobium, PSB, Growth parameters, Pea

How to cite this paper: Khan, Insaf, Singh, Devendra and Jat, Bhanwar Lal (2017). Effects of biofertilizers on plant growth and yield characters of Pisum sativum L. Adv. Res. J. Crop Improv., 8 (1) : 99-108, DOI : 10.15740/HAS/ARJCI/8.1/99-108.

Paper History : Received : 19.04.2017; Revised : 12.05.2017; Accepted : 20.05.2017 